\title{
Nutrient effects on ovulation rate, ovarian function and the secretion of gonadotrophic and metabolic hormones in sheep
}

\author{
J. A. Downing and R. J. Scaramuzzi \\ CSIRO Division of Animal Production, P.O. Box 239, Blacktown, New South Wales 2148 , \\ Australia
}

Keywords: sheep; ovulation rateł nutrition; gonadotrophins; metabolic hormones

\section{Introduction}

Nutrition is one of the most significant influences on the ovulation rate of sheep. In the extensive systems of husbandry practised in many countries most animals will experience at least one period of nutritional deprivation during their lifetime. Under these conditions reproductive performance is often sub-optimal, an effect usually attributed to poor nutrition. The effects of poor nutrition on reproductive performance are evident in many events in the reproductive cycle and the one which this paper will highlight is ovulation.

\section{Historical overview}

The upper limit of ewe prolificacy is determined genetically and depends upon the number of ova released at ovulation. The degree to which a ewe can express this genetic potential is influenced greatly by environmental factors. One of these is the nutritional regimen before and at mating. The knowledge that nutrition is important in relation to lambing rate is not new (Youatt, 1837) and was first noted with the observation that ewes in good condition or on good quality pasture gave birth to a higher percentage of twin lambs. The observation that heavier ewes produced more lambs than did lighter ewes of the same breed (Heape, 1899) was followed, in the early part of this century, by numerous similar reports.

Short periods of improved nutrition before and during mating were shown to be sufficient to increase the proportion of twin lambs born (Marshall, 1904, 1905, 1908; Nichols, 1924; Marshall \& Potts, 1921). This response is referred to as 'flushing'. The effect of absolute liveweight and of 'flushing' on ewe reproductive performance has formed the basis of much of the research into the interaction of nutrition and ewe reproduction during the past 50 years.

\section{Relationship between liveweight and ovulation rate}

The first scientific report that heavier sheep produce more lambs was based on information gathered from questionnaires sent to individual sheep farmers (Heape, 1899). In many cases the replies contained little data on liveweight, liveweight change or body condition. Wallace (1958) found that in one of his experimental flocks the lambing percentage followed closely the liveweight at mating. He later confirmed that a substantial part of the differences in lambing percentages were related to differences in ewe liveweight (Wallace, 1961). Analysis of a large volume of data, collected over many years, led to the conclusion that liveweight at mating has a considerable influence on the reproductive rate of ewes, especially the rate of twinning (Coop, 1962). From a between-flock 
analysis he estimated that the twinning rose by $5 \cdot 3 \%$ for each additional $4.5 \mathrm{~kg}$ of liveweight. Studies of the interaction between nutrition and reproduction were subsequently extended to include ovulation rate (Killeen, 1967; Allison, 1968; Edey, 1968; Gunn et al., 1969; Cumming, 1977; Smeaton et al., 1981; Kelly \& Johnstone, 1982; Kelly et al., 1983). Morley et al. (1978) in an extensive analysis of data from various published reports concluded that there was a relationship between liveweight and ovulation rate between groups of ewes and in some cases within groups of ewes. In most of the breeds studied, it was reported that for each additional kilogram in liveweight there was a $2 \cdot 0-2 \cdot 5 \%$ increase in ovulation rate and a $1 \cdot 5-2 \cdot 0 \%$ increase in lambs born per ewe. However, the relationship varied widely depending upon whether it was measured within flocks of a similar genetic constitution or between flocks and breeds. Cumming (1977) found that, within flocks, ovulation rate increased from 0 to 0.44 for each additional $10 \mathrm{~kg}$ of liveweight, the increase for most flocks being 0-25-0.30.

The liveweight of a ewe is a combination of body size and body condition and as such liveweight is not a good measure of a ewe's body nutrient reserves. In a study by Ducker \& Boyd (1977), body size had no effect on mean ovulation rate of ewes in the same body condition. In Scottish Blackface ewes, ovulation rate was positively related to body condition at mating (Gunn et al., 1969, 1972; Gunn \& Doney, 1975). Liveweight per se is therefore not a suitable variable to consider in studying ovulation responses in relation to pre-mating nutrition. Body condition, a reflection of the ewe's body tissue reserves, is more appropriate.

\section{Relationship between liveweight change, feed intake and ovulation rate}

Short periods of improved nutrition before and during mating increase the proportion of ewes bearing twins (Heape, 1899; Marshall, 1905; Nichols, 1924, 1926; Underwood \& Shier, 1941; Darrock et al., 1950; Wallace, 1951, 1953; Coop, 1966; Cumming, 1977; Gunn et al., 1984a). This practice has been termed 'flushing' and described thus "The practice of 'flushing' consists of giving ewes which are in fairly poor condition an improved diet for a few weeks before mating so that they are in rapidly rising condition when they meet the ram" (Thompson \& Aitken, 1959). Responses to 'flushing' have not always been observed (Hart \& Miller, 1937; Tribe \& Seebeck, 1962). Clark (1934) first suggested that variability in response might be due to differences in body condition, with ewes in good condition having a high ovulation rate and therefore being close to their genetic potential for this character. Continuous maintenance of ewes in good condition will maintain high ovulation rates and generally it is accepted that the greatest benefit from 'flushing' is from ewes in moderate condition. Coop (1962) calculated that half the response to 'flushing' could be accounted for by differences in absolute liveweight and that the remainder could possibly be related to rapidly rising body condition. He introduced the terms 'static' and 'dynamic' to distinguish between these effects. Further research led him to believe that there existed a distinct 'dynamic' effect that was related to 'flushing' (Coop, 1966). When ewes were 'flushed' for one oestrous cycle the lambing percentage increased by $10 \%$ and included a 'static' component which when deducted left a 5-6\% increase attributable to the 'dynamic' component (Coop, 1966).

Not until the late 1960 s was a large effort put into examining the relationship between liveweight change and ovulation rate (Killeen, 1967; Allison, 1968; Edey, 1968; Gunn et al., 1969). Morley et al. (1978) concluded that there is little doubt as to the existence of a 'dynamic' effect, related to oyulation rate, although it is far from general even when liveweight is changing rapidly at the time of mating.

'Flushing' includes two processes, firstly an increase in nutrient intake, either by an increase in the level of intake and/or intake of better quality feed and, secondly, a resultant improvement in body condition. Alterations in body condition are generally measured as liveweight change once gut fill has been taken into account but body condition can also be measured as a semi-quantitative score (Russel et al., 1969). However, it is only in recent times that the relationship between body 
condition at mating and pre-mating nutrition has been considered. In Edinburgh, at the former Hill Farming Research Organization, it was observed that ovulation rate was positively and significantly related to body condition at mating but not significantly related to the level of pre-mating nutrition when ewes were in good (condition score 3.0 ) or moderately good (condition score 2.5) condition (Gunn et al., 1969, 1972; Russel et al., 1969; Gunn \& Doney, 1975). The work by Gunn et al. (1969) suggested that with ewes in poor condition at mating ovulation rate might be related to the level of pre-mating nutrition. In a later study it was found that, in cases of moderate body condition (condition score $2 \cdot 0$ ), ovulation rate was positively and significantly related to the level of pre-mating nutrition but that this was not the case in ewes of higher body condition (Gunn et al., 1984b).

Relationships between liveweight, liveweight change or body condition with ovulation rate are just that, relationships. They themselves do not influence ovulation rate or reproductive events but are the consequence of past and present nutritional influences. In our efforts to understand how nutritional influences can increase ovulation rate (Scaramuzzi, 1986) we have followed the reasoning of Lindsay (1976). He made the suggestion that the effect of nutrition on reproductive processes should be thought of in terms of the ewe's 'net nutritional status', a term which encompasses both the endogenous and exogenous sources of nutrients available to the ewe. If considered in these terms the changes in reproductive traits associated with nutritional influences can be related to major metabolic changes. These metabolic changes are a consequence of decreasing or increasing feed intake and the associated utilization or storage of nutrients in body reserves.

\section{Feeding lupin grain to increase ovulation rate}

Lupin grain is a supplement high in available energy and protein which can be given to ewes to increase ovulation rate. Studies in the early 1970 s showed that supplementation with lupin grain increased ovulation rate and the number of lambs born (Knight et al., 1975). The increase in lambing rate resulted from increases in the percentage of lambs lambing (fertility) and in the number of lambs born to each lambing ewe (prolificacy). Lupin grain supplements given to ewes grazing either low quality subterranean clover pasture or wheaten stubble increased ovulation rate and the extent of the response was positively related to the level of supplementation (Lightfoot \& Marshall, 1974). Since these studies there have been numerous reports of increased ovulation rate following lupin grain supplementation (Kleeman \& Cutten, 1978; Knight, 1980; Gherardi \& Lindsay, 1980; Nottle et al., 1986; Stewart \& Oldham, 1986; Nottle et al., 1988; Teleni et al., 1989).

Ovulation rate increases after lupin grain supplementation occur in as little as 6 days after the start of feeding (Lindsay, 1976; Oldham \& Lindsay, 1984), a period too short to detect major changes in liveweight. Nottle et al. (1986) increased ovulation rate in ewes by supplying lupin supplements for 5-7 days before induced luteolysis. The supplements were given on Days 3-9, 7-11 or 11-0 of the oestrous cycle and in each case there were similar positive responses. This work has indicated that the critical time for supplementation is the 6 days before luteolysis. This observation has been confirmed by Stewart \& Oldham (1986) who found that 4 days of lupin supplementation at a critical time in the oestrous cycle will increase ovulation rate. The lupin grain had to be fed on Days $9-12$ of the cycle preceding oestrus. In our experiments we have used this knowledge that responses can be obtained in a short time and that the period of supplementation is critical to develop a model for testing possible mechanism(s) by which short-term nutrient supply may influence ovulation rate.

\section{Nutrition and gonadotrophins}

\section{Gonadotrophin concentrations in the pituitary gland}

Nearly 40 years ago it was postulated that the ovaries of ewes fed on a high plane of nutrition would contain more follicles, with an antrum, than would the ovaries of ewes fed a low plane of 
nutrition and that, with a high plane, a given quantity of gonadotrophin would cause greater ovarian stimulation (Hammond, 1952). Results obtained from investigations into variation in ovulation responses to pregnant mares' serum gonadotrophin (PSMG) treatment did not support the second part of Hammond's hypothesis (Wallace, 1954). The ovulation rate in response to PMSG was not related to nutritional treatment but, in ewes fed a sub-maintenance diet, administration of PMSG increased the number of follicles present, suggesting that nutritional effects on ovarian activity in ewes were related to the concentration of gonadotrophin present in the blood reaching the ovary.

Giving grain to ewes on a diet of hay did not increase pituitary gland gonadotrophin concentrations but did increase pituitary weight and therefore total LH and FSH content (Bellows et al., 1963). Ovarian response to endogenous gonadotrophin was not increased by the grain supplementation. In a similar study, grain feeding of ewes increased pituitary gland weight and appeared to increase LH concentration in the gland at all stages of the oestrous cycle examined, but had no apparent effect on the concentration of FSH (Howland et al., 1966). The parallelism between total gonadotrophin potency and follicular development at all stages of the oestrous cycle investigated suggested that there was greater hormone production in grain-fed ewes than in ewes fed hay alone.

\section{Gonadotrophin concentrations and lupin grain supplements}

Brien et al. (1976) found that ewes given a lupin grain supplement had a higher mean plasma concentration of FSH over the 5 days before oestrus and that the difference between the values at 5 days and I day before oestrus was significantly greater than that in ewes not given a supplement. When ewes were fed various types of protein supplements, ovulation rate was increased and in the ewes with multiple ovulations there tended to be increased FSH concentrations before ovulation (Davis et al., 1981). Similarly, supplementation with lupins was reported to be associated with higher mean plasma FSH values 4 days before oestrus (Knight et al., 1981). These authors also reported increased plasma oestradiol concentrations in lupin-supplemented ewes, indicating greater follicular development. When oestradiol-implanted, ovariectomized ewes were given lupin grain for 7 days, plasma FSH values increased within $24 \mathrm{~h}$ when compared to similar ewes fed wheaten chaff alone; the increased FSH levels were present for at least 7 days after supplementation ceased (Nottle et al., 1987). These observations suggest that the increased FSH is due to responses at the level of the hypothalamo-pituitary axis. Feeding ewes a high protein diet led to an increased ovulation rate, which was associated with elevated FSH concentrations on Days 2, 3, 4 and 6 before oestrus compared to ewes fed a low protein diet (Smith, 1988). The increases in FSH occurred at a time when it is considered that elevated FSH values can increase ovulation rate in the ewe (McNatty et al., 1985). Other reports have suggested that the nutritional stimulus does not involve changes in circulating FSH. There were no differences in plasma FSH concentrations in ewes fed at one-third maintenance, maintenance or twice maintenance levels of chopped lucerne hay even though there were significant differences in ovulation rate (Findlay \& Cumming, 1976). Lupin supplements have been shown to increase ovulation rate without differences in the pattern of release of LH or FSH in either the luteal or follicular phase of the oestrous cycle (Radford et al., 1980; Scaramuzzi \& Radford, 1983). These results led to the suggestion that lupin grain supplementation increased ovulation rate by altering the reponsiveness of the ovary to gonadotrophins rather than by changing gonadotrophin concentrations. Supplementation of the diet of intact ewes with lupin grain did not lead to an increase in values of plasma FSH or a change in the LH pulse pattern (Ritar \& Adams, 1988). When ovariectomized ewes were given implants of oestradiol and fed a supplement of lupin grain there was no observed increase in FSH concentrations associated with lupin supplementation but there was an enhanced variability in FSH values (Ritar \& Adams, 1988). The conclusions reached from these observations were that lupin grain supplementation did not increase FSH concentrations and that the differences observed in ovulation rate in intact ewes after lupin grain supplementation could be due to increased ovarian sensitivity to gonadotrophins. 


\section{Gonadotrophins and the level of pre-mating feed intake}

When on a high or a low level of intake during the weeks before mating, ewes showed no differences in gonadotrophin profiles in the luteal phase of the oestrous cycle. During the follicular phase, ewes with a high nutrient intake had a significantly elevated LH pulse frequency and a nonsignificant increase in FSH concentrations, suggesting that the level of pre-mating food intake influenced ovulation rate by acting on the final stages of follicle development (Rhind et al., 1985). In two groups of ewes having the same body condition but on high or moderate intakes there was no difference in mean FSH concentrations and the LH pulse values in the luteal or follicular phase of the oestrous cycle (Rhind et al., 1989a). The fact that no increase in LH pulse frequency was observed during the follicular phase is in contrast to an earlier result from the same group (Rhind et al., 1985). In a similar study, Rhind et al. (1989b) looked at the effect of body condition on plasma LH and FSH concentrations. In ewes in high or low body condition there were no differences in FSH or LH pulse characteristics in the luteal or the follicular phases of the oestrous cycle. The relationships between nutrition, ovulation rate and gonadotrophin patterns are difficult to interpret due to inconsistencies in response to nutrition from one experiment to another, one of the big problems plaguing research in this area. We have felt that this problem is sufficient to justify a new experiment aimed at measuring plasma gonadotrophin values in ewes fed a lupin supplement.

\section{Plasma gonadotrophin and metabolic hormone concentrations in ewes fed a lupin grain supplement}

In an attempt to understand the mechanism(s) underlying the ovulation responses to short-term nutrient supply we designed a series of experiments, the first of which described the plasma concentrations of gonadotrophic and some metabolic hormones during the late luteal phase in ewes fed a lupin grain supplement. Border Leicester $\times$ Merino ewes were fed a diet of hammer-milled oaten straw, supplemented with minerals, at a rate of $800 \mathrm{~g}$ per day. Oestrus was synchronized by two injections of a commercially available synthetic prostaglandin (Estrumate: ICI Australia) given 10 days apart with the first being 5 days after the start of feeding. From previous studies, oestrus was expected, in $90-95 \%$ of the ewes, $42-48 \mathrm{~h}$ after the second of these injections. On an estimated Day 2 of the cycle, 11 ewes were each given lupin grain starting at $150 \mathrm{~g}$ per day and increasing to $750 \mathrm{~g}$ per day by Day 6 and thereafter continued at $750 \mathrm{~g}$ per day until Day 13 of the cycle. The lupin grain supplement was given at $09: 00 \mathrm{~h}$ daily and any residues removed at 15:00 h; the ewes were then offered $800 \mathrm{~g}$ of the straw diet. The remaining 12 control ewes were offered $800 \mathrm{~g}$ of the straw diet at 09:00 h daily. At the end of the supplementation period all ewes were given a third injection of PG and 10 days later their ovaries were examined by endoscopy to determine ovulation rate.

On Day 11 of the cycle, $3 \mathrm{ml}$ blood samples were taken via indwelling jugular venous catheters, every $20 \mathrm{~min}$ for $24 \mathrm{~h}$ starting at 10:00 h, and the plasma was assayed by radioimmunoassay (RIA), for $\mathrm{LH}$, growth hormone, prolactin and FSH. Plasma insulin levels were determined in samples collected $1-5 \mathrm{~h}$ and $2 \mathrm{l}-25 \mathrm{~h}$ after feeding.

The supplementation with lupin grain resulted in a higher ovulation rate $(2 \cdot 6 \pm 0 \cdot 2$ vs $1.9 \pm 0.2 ; P=0.073$ ). This ovulation rate response was achieved without a significant change in plasma concentrations of FSH (Fig. 1) or the LH pulse characteristics (pulse interval, pulse amplitude and basal concentration), over the 24-h period of sampling (J. A. Downing, J. Joss \& R. J. Scaramuzzi, unpublished results). Supplementation with lupin grain increased plasma prolactin ( $29 \pm 4$ and $18 \pm 4 \mathrm{ng} / \mathrm{ml} ; P=0.036)$, but growth hormone levels were lower $(2.8 \pm 0.5$ and $9.9 \pm 0.6 \mathrm{ng} / \mathrm{ml} ; P<0.001)$. Plasma insulin concentrations were significantly elevated at both sampling periods in the lupin-supplemented ewes $(2.6 \pm 0.6$ and $0.6 \pm 0.2 \mathrm{ng} / \mathrm{ml}(P=0.007)$ from 1 to $5 \mathrm{~h}$ after feeding; $3.7 \pm 1.3$ and $0.5 \pm 0.2 \mathrm{ng} / \mathrm{ml}(P=0.005)$ from 21 to $25 \mathrm{~h}$ after feeding).

The response in ovulation rate to supplementation with lupin grain was not associated with changes in LH or FSH on Days 11-12 of the oestrous cycle, but the plasma concentrations of 
prolactin, insulin and growth hormone did change and such changes might be causally related to the ovulation rate increase in response to lupin grain supplementation.

\section{Nutritional effects on follicle development}

\section{Follicle growth during the oestrous cycle}

The sheep ovary contains a large population of primordial follicles and a smaller number of follicles at various stages of development (Cahill et al., 1979). The growth of a primordial follicle to ovulation takes an estimated 6 months (Fig. 2; Cahill \& Mauleon, 1980). Once a primordial follicle starts growing it passes through a pre-antral phase lasting an estimated 130 days, at the end of which it will have attained a diameter of approximately $0.2 \mathrm{~mm}$ (Turnbull et al., 1977; Cahill, 1981). It has been estimated that 3-4 follicles/day enter the pre-antral growth phase and that growth from the end of the pre-antral phase until the ovulatory stage takes an additional 34-43 days (Turnbull et al., 1977). Of this time it takes an estimated 25-34 days to reach a diameter of $0.5 \mathrm{~mm}$. 5 days to grow to about $2 \cdot 2 \mathrm{~mm}$ and a further 4 days to reach $4-5 \mathrm{~mm}$ (Fig. 2).

In sheep, atresia is rare in follicles smaller than $0.5-1.0 \mathrm{~mm}$ in diameter and approximately $50-70 \%$ of the $5-24$ follicles/ewe $>1.0 \mathrm{~mm}$ in diameter are atretic (Brand \& de Jong, 1973; Turnbull et al., 1977; McNatty, 1982). Accordingly, at the time of oestrus there are very few follicles $>1.0 \mathrm{~mm}$ in diameter that are non-atretic and at the time of ovulation there will only be $1-2$ follicles $>5.0 \mathrm{~mm}$ in size capable of ovulating.

In Fig. 2 we have associated, with particular stages of the oestrous cycle, the growth of a follicle to ovulation. Working back from the expected time of ovulation, the time when a potential ovulatory follicle is most susceptible to atresia $(1-2.5 \mathrm{~mm}$ in diameter) is at about Day 9-13 of the oestrous cycle, which is when lupin grain supplementation will increase ovulation rate. Short-term nutritional effects on ovulation rate could involve changes to the level of atresia found in the population of follicles undergoing final stages of growth and development.

\section{Nutrition and follicle number}

Ewes given a grain supplement have a greater total follicular fluid weight compared with ewes fed hay alone (Bellows et al., 1963). This work suggests that there was an increase in the follicle number and/or size. The feeding of ewes with a sub-maintenance ration was reported to alter the distribution of follicle sizes in the ovary (Allen \& Lamming, 1961). In the same experiment, 'flushing' ewes increased the number of follicles $<2.0 \mathrm{~mm}$ in diameter and the number of follicles $2-3 \mathrm{~mm}$ in diameter compared with ewes fed the sub-maintenance diet. When Dufour \& Matton (1977) fed ewes at two different energy levels from Day 10 of the oestrous cycle they found no difference in ovulation rate. When the 4 largest follicles on the ovary were marked they found that the $3 \mathrm{rd}$ and 4 th largest follicles were significantly larger in the ewes on the high energy diet. When they compared follicles from single and double ovulations for both treatments they found that in ewes with double ovulations the second largest follicle marked at oestrus was significantly larger than that observed with single ovulations. It is probable that the size of the second largest follicle at oestrus is critical in determining the rate of twin ovulation. When Haresign (1981) fed ewes a maintenance or a twice maintenance ration he found, at oestrus, a similar number of follicles $1-2 \mathrm{~mm}$ in diameter in the ovaries of both groups, larger numbers of follicles $2-3 \mathrm{~mm}$ in diameter in ewes fed the twice maintenance ration and no difference in follicles $>3 \mathrm{~mm}$. At $18 \mathrm{~h}$ after oestrus the ewes on twice maintenance had more follicles $>3 \mathrm{~mm}$; this difference was significant by $48 \mathrm{~h}$. These observations led Haresign (1981) to suggest that 'flushing' did not affect the number of small follicles in the ovary and as such did not affect the early stages of follicle development but increased ovulation rate by preventing atresia of $2-3 \mathrm{~mm}$ follicles. This concept is supported by a study in which lupin grain supplementation for 7 days did not affect the number of follicles $>2 \mathrm{~mm}$ in 


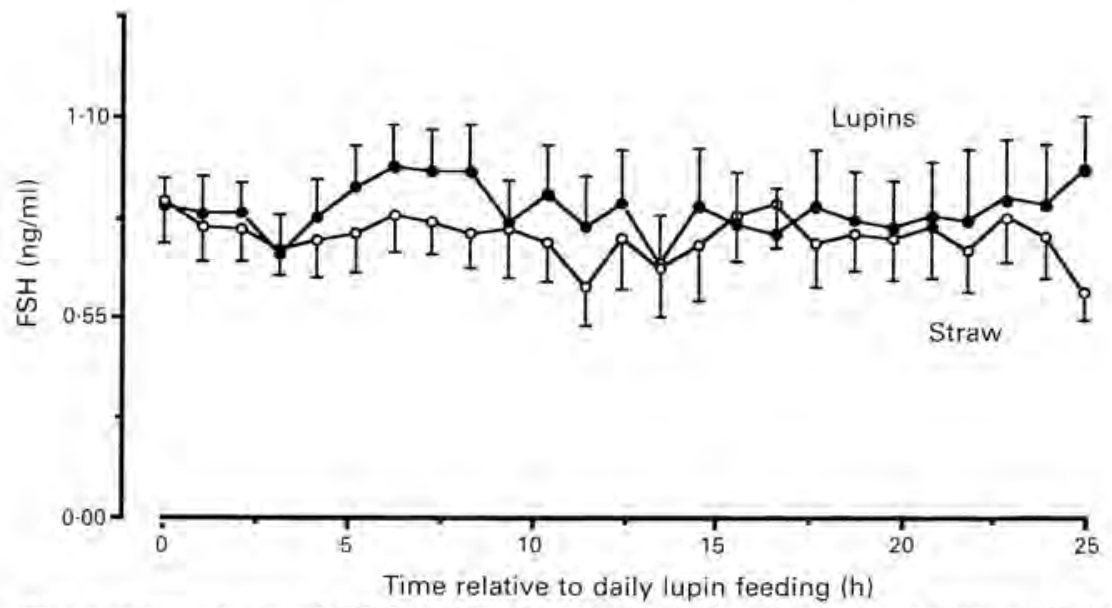

Fig. 1. The concentrations of FSH in hourly samples of jugular venous plasma during the mid-luteal phase of the oestrous cycle (Day 11), from ewes fed a basal diet of wheaten straw containing minerals (Straw; $\mathrm{N}=12$ ) or the basal diet supplemented with $750 \mathrm{~g}$ lupin grain (Lupins; $\mathrm{N}=11$ ).

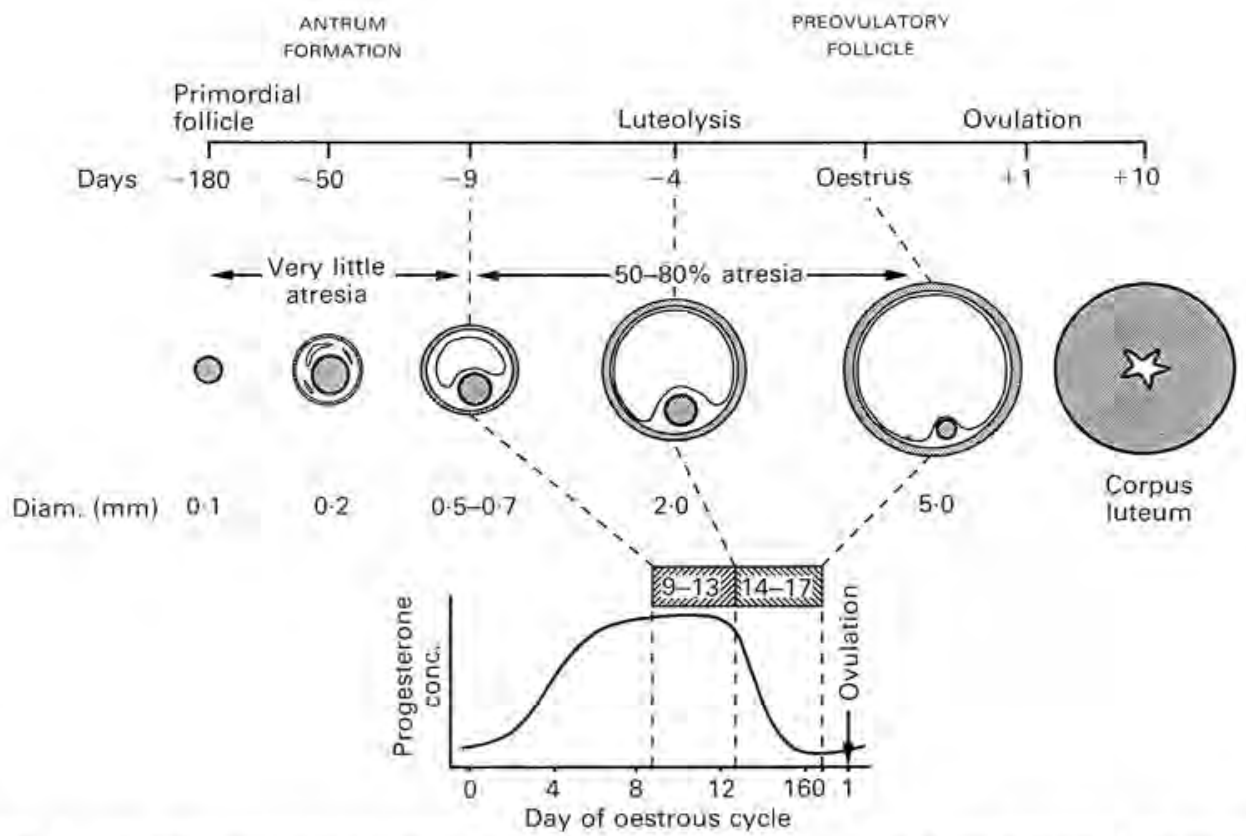

Fig. 2. The time relationship between the growth and development of primordial follicles to Graafian follicles capable of ovulation and the oestrous cycle (see text for details).

diameter on the ovaries at oestrus whereas $48 \mathrm{~h}$ after oestrus there were fewer atretic follicles $>2 \mathrm{~mm}$ in diameter (Nottle et al., 1986). In a further study (Rhind \& McNeilly, 1986) follicle sizes in ovaries from two groups of ewes, one in high body condition score and the other in low body condition score, were determined. Ovaries from ewes in the high body condition group had similar numbers of small follicles but there were more follicles of $>4 \mathrm{~mm}$ in diameter present. They concluded that body condition effects on ovulation rate probably involved changes in the number of 
large follicles that developed and were capable of ovulation. In two groups of ewes which differed in mean bodyweight by $15 \mathrm{~kg}$, the heavier ewes had more follicles $>2 \mathrm{~mm}$ in diameter on the ovarian surface in the late luteal phase, and morphological studies showed that more of these follicles were non-atretic (Xu et al., 1989).

\section{Nutrition, gonadotrophins and follicle development}

Both FSH and LH are necessary for the development and maintenance of antral follicles. FSH is involved in the growth and differentiation of follicles within the ovary (Greep, 1961; Moore \& Greenwald, 1974), in the development of LH receptors on the granulosa cells (Hsueh et al., 1984) and in granulosa cell aromatase activity (Richards, 1980). In the later stages of development of a follicle, follicular health can be estimated by the ability to produce oestradiol because the number of FSH receptors per granulosa cell decreases as follicles undergo atresia (Carson et al., 1979). In sheep final maturation and development of the antral follicle to ovulation after luteolysis depends on an increase in the frequency of pulsatile secretion of LH (Baird \& MCNeilly 1981). Receptors for $\mathrm{LH}$ are present on the thecal cells of atretic and non-atretic antral follicles but are confined to the granulosa cells in large non-atretic follicles (Carson et al., 1979; England et al., 1981), Such follicles are defined as activated and are believed to be fully mature and capable of ovulation.

Ovulation rate depends on the number of activated follicles present at the LH surge (England et al., 1981; Webb et al., 1984; Webb \& Gauld, 1985). Activated follicles are characterized by the presence of LH receptors on the granulosa cells and the development of these follicles is dependent on exposure to FSH. We propose that the mechanism(s) by which short-term nutrition influences ovulation rate involves a decrease in the level of atresia during the final stages of follicle development, giving rise to an increased number of activated follicles at the time of the LH surge. This in turn requires changes in the concentrations of circulating gonadotrophins or in the effectiveness of gonadotrophin action at the ovary.

\section{Some mechanistic models}

Ovarian follicles are small structures which require little protein or energy during growth and maturation. The effect of nutrition on ovulation rate is, therefore, one of environmental regulation of a key biological process. The nature of this regulation is unknown but is probably connected with the hormonal control of the ovary. This occurs within a feedback system, in which the pituitary gland, controlled by the brain, secretes the gonadotrophins, LH and FSH, which stimulate ovarian function (Fig. 3). Hormonal feedback from the ovary, principally oestrogen, progesterone and inhibin, negatively regulates the secretion of $\mathrm{LH}$ and $\mathrm{FSH}$. It has long been assumed that nutrition acts by interfering with this negative control system. Two hypotheses concerning the mechanism by which nutrition influences ovulation rate have been advanced. However, both are based upon the a-priori assumption of hormonal control, and furthermore, they are not mutually independent. The first postulates that the effect of nutrition on ovulation rate is associated with effects leading to changes in blood concentrations of LH and FSH (the hypothalamo-pituitary hypothesis). The second postulates that the effect of nutrition on ovulation rate is mediated by a direct action on the ovary. This does not involve changing levels of blood gonadotrophins (the ovarian hypothesis).

\section{The hypothalamo-pituitary hypothesis}

This hypothesis predicts that nutritional influences on ovulation rate are mediated by elevated gonadotrophin concentrations at some critical stage of follicle development. The effects predicted by this hypothesis can arise in several ways: (1) altering inputs from higher levels within the central 


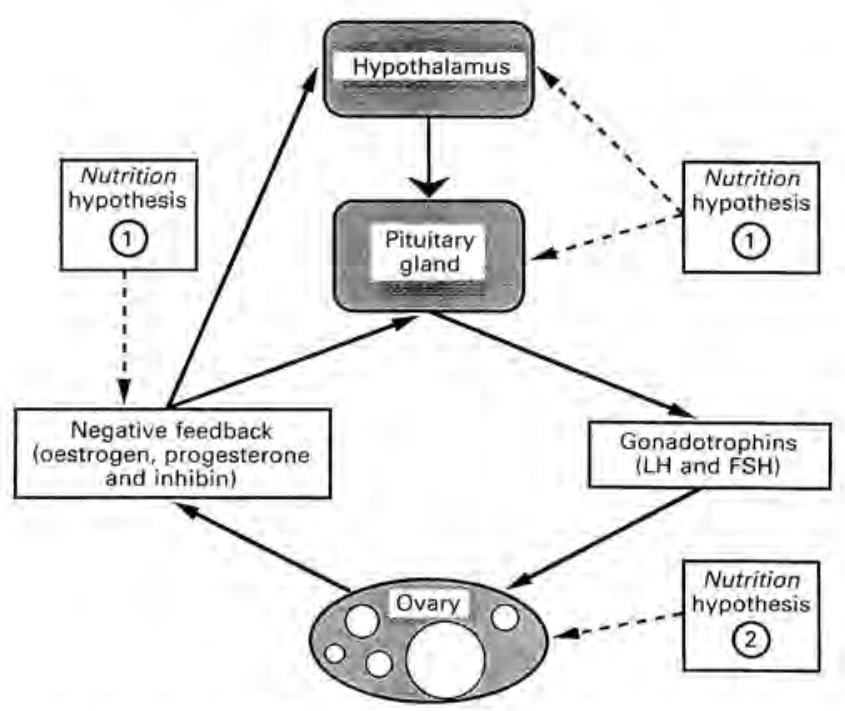

Fig. 3. Possible sites of action for the nutritional regulation of ovulation rate in the ewe. Hypothesis 1, variation in gonadotrophin concentrations, and Hypothesis 2, modulation of ovarian responses to constant gonadotrophin values.

nervous system to increase hypothalamic secretion of GnRH into the hypophysial portal system; (2) altering hypothalamo-pituitary activity to increase the secretion of gonadotrophins; (3) decreasing feedback action of ovarian hormones, through increased rate of peripheral metabolism of the ovarian hormones; and (4) decreasing the peripheral metabolism of gonadotrophins.

Several studies have been conducted to determine whether $\mathrm{LH}$ and FSH levels are directly influenced by nutrition. In general results have been variable and difficult to interpret (see p. 212). The secretion of the gonadotrophins by the pituitary is in a dynamic balance with hormonal secretions from the ovary. Any increase in secretion of LH or FSH would increase ovarian function which would, in turn, reduce gonadotrophin secretion to counteract the deviation and maintain homeostasis. The blood concentrations of gonadotrophins cannot be interpreted without concurrent knowledge of the circulating levels of ovarian hormones. The homeostatic balance which exists between the ovary and the hypothalamo-pituitary axis and how nutrition might influence this balance to regulate the number of activated follicles needs to be studied.

\section{The ovarian hypothesis}

This hypothesis postulates that nutrition influences ovulation rate by enhancing gonadotrophin action at the ovary and, as such, increases ovulation rate without an increase in circulating gonadotrophin concentrations. The effects predicted by this hypothesis can arise in at least two ways: (1) a specific nutrient effect on ovarian responsiveness to LH or FSH leading to an increase in the number of activated follicles; and (2) altered levels of metabolic hormone(s) in response to a changing nutrient status leading also to an increase in the number of activated follicles.

High intakes of energy (including high protein diets), lead to altered levels of some metabolic hormones, such as growth hormone, prolactin and/or insulin (Beitz, 1985). These hormones could form a link between nutrition and ovulation rate. It is now becoming established, largely from studies of rat tissues, that the metabolic hormones can influence ovarian function by modulating gonadotrophin action (Tonetta \& diZerega, 1989) and therefore any alteration in the levels of the metabolic hormones at the ovary will have implications for ovulation rate. 


\section{The effect of liveweight}

An hypothesis for the effects of nutrition on ovulation rate must also take account of the well established 'static' and 'dynamic' effects of liveweight as well as the effects of short-term nutrition associated with Iupin grain supplementation. These long-term 'liveweight' effects of nutrition on ovulation rate might work through mechanisms independent of those involved in the short-term responses we are considering in this paper. On the other hand, all of these nutritional effects on ovulation rate might be indistinguishable from each other.

Long-term mechanisms involving increased rates of follicle growth are suggested by the observation that sheep with higher liveweight have increased numbers of non-atretic antral follicles (Haresign, 1981; Xu et al., 1989). There is a considerable literature showing that obesity affects circulating levels of androgenic and oestrogenic hormones in women (Hemsell et al., 1974). A similar mechanism in sheep could link liveweight and ovulation rate because changes in steroidal feedback may mediate nutritional effects on ovulation rate (the hypothalamo-pituitary hypothesis: mechanism 3). Indeed, there is evidence, in sheep, that the concentration of circulating oestrogen is influenced by liveweight; the concentration of oestrogen receptors in the uterus of ovariectomized ewes varies inversely with liveweight and, since the concentration of oestrogen receptors is determined by oestrogen itself, these data indicate that liveweight can affect oestrogen levels in sheep (Adams \& Ritar, 1986; Atkinson \& Adams, 1988). We have found only one report investigating the effects of nutrition on peripheral concentrations of oestrogen in sheep (Knight et al., 1981).

\section{Energy or protein?}

\section{Ovulation rate and energy}

Over the past 20 years considerable effort has been devoted to distinguishing between the relative importance of protein and energy intake as the stimulus leading to increases in ovulation rate arising from 'flushing'. Many of these studies are confounded by the fact that ruminal degradation of dietary protein together with synthesis of microbial protein consequent to the ruminal digestion of carbohydrate poses major problems in the interpretation of the effects of dietary protein and energy on reproductive function. Very early on it was shown that the feeding of high levels of grain would lead to increases in ovulation rate in ewes (Clark, 1934). The high energy content of the grain was considered to be the stimulus responsible for this increase (Howland el al., 1966). The feeding of a high level of fat or starch to ewes has been shown to increase ovulation rate relative to that of ewes on a basal ration or ewes fed a low level of fat or starch (Memon et al., 1971). In contradiction to these observations, no response in ovulation rate occurred in ewes fed $400 \mathrm{~g}$ starch per day (Nottle et al., 1986). Using a $2 \times 2$ factorial design in which ewes were fed two levels of energy and two levels of protein, Memon et al. (1969) found that feeding high energy levels increased ovulation rate irrespective of the level of protein fed. This increase was due largely to an increase in the percentage of ewes with multiple ovulations. Feeding high energy or low energy levels from Day 10 of the oestrous cycle did not influence ovulation rate (Dufour \& Matton, 1977).

\section{Ovulation rate and protein}

Diets varying in total energy and protein content, gave responses (in terms of lambing percentage) indicating that the relative importance of protein or energy alone was inversely related to the amount of each provided in the diet (Torell et al., 1972). Fletcher (1981) found that increased protein only stimulated ovulation rate in ewes previously fed low levels of protein. Ovulation rate was increased when available crude protein rose from 35 to $70 \mathrm{~g} /$ day, but when protein intake increased from 70 to $150 \mathrm{~g}$ /day there was no increase in ovulation rate. Results of feeding diets of a similar energy level but with different levels of protein and at different levels of intake indicated that there were effects of both energy and protein on the percentage of ewes with multiple ovulations 
(Smith, 1985). There was a linear response to energy level and a step-wise response to protein level in the diet.

Lindsay (1976) considered that the high protein content of lupin grain was the nutrient stimulus that increased ovulation rate. The feeding of isocaloric energy supplements of lupin grain or wheat altered ovulation rate in summer but the lupin grain supplement also increased ovulation rate in the autumn (Rizzoli et al., 1976).

The feeding of high quality protein in the form of formaldehyde-treated casein to increase ovulation rate has met with varied success. Corbett \& Edey (1977) did not increase ovulation rate in ewes by feeding $60 \mathrm{~g}$ formaldehyde-treated casein/day. This result led the authors to consider that the effects of 'flushing' were principally due to increases in energy intake. In another report there was no response to $100 \mathrm{~g}$ formaldehyde-treated casein/day (Teleni et al,, 1989). However, feeding ewes $160 \mathrm{~g}$ formaldehyde-treated casein/day increased ovulation rate and the response was of a magnitude similar to that obtained by feeding $500 \mathrm{~g}$ lupin grain/day; the addition of starch to the formaldehyde-treated casein gave no additional response (Nottle et al., 1988).

\section{Ovulation rate and supplements that avoid fermentation in the rumen}

One approach to assessing the importance of various nutrients in their ability to stimulate ovulation rate has been to infuse these nutrients post-ruminally into the abomasum or the jugular vein. The infusion of 2 types of protein or of glucose into the abomasum of ewes increased the percentage of ewes with multiple ovulations (Cruikshank et al., 1988), but the response to glucose was not significant. Teleni et al. (1989) infused energy yielding substrates directly into the venous circulation and measured ovulation rate. The infusion of $525 \mathrm{mmol}$ glucose/day and/or $1222 \mathrm{mmol}$ acetate/day raised ovulation rate to a degree similar to the daily feeding of a $750 \mathrm{~g}$ lupin grain supplement.

\section{Effects of infusing glucose on ovulation rate and hormone concentrations in the ewe}

The effects of infusing glucose into the peripheral circulation of ewes for 5 days on ovulation rate and hormone concentrations were studied in Border Leicester $\times$ Merino ewes. The 23 ewes were housed in individual pens and fed to appetite a diet of ground oaten straw, supplemented with minerals. Oestrus was synchronized by two injections of a commercially available synthetic prostaglandin (Estrumate: $\mathrm{ICl}$ Australia) given 10 days apart, the first injection being 4 days after the start of feeding. At 9 days after the second $P G$ injection, all ewes were fitted with indwelling catheters in both jugular veins. On the following day, all ewes were infused with physiological saline from $17: 00 \mathrm{~h}$. On the next day, starting at 10:00 h 12 ewes were each infused with $60-65 \mathrm{mmol}$ glucose/h for 5 days. The remaining 11 ewes received saline infusion. At the end of the infusion period all ewes were given a third injection of PG and 10 days later their ovaries were examined by endoscopy to determine ovulation rate.

On the first day of the infusion period, samples of blood $(3 \mathrm{ml})$ were taken every $2 \mathrm{~h}$. Over the first $48 \mathrm{~h}$ of the glucose infusion samples were taken every $4 \mathrm{~h}$. On the 3 rd day of glucose infusion samples were taken every $20 \mathrm{~min}$ for $24 \mathrm{~h}$ and then continued every $4 \mathrm{~h}$ until $52 \mathrm{~h}$ after the end of the infusion period. In all, the blood sampling lasted for 8 days and $4 \mathrm{~h}$. Plasma was separated and stored frozen. Samples collected every $20 \mathrm{~min}$ were assayed for $\mathrm{LH}$, and samples collected at 2 - and 4-h intervals were assayed for growth hormone, prolactin and FSH. Insulin was determined in 20-min samples collected in the periods $0-4 \mathrm{~h}$ and 18-22 $\mathrm{h}$ after fresh feed was given at 09:00 $\mathrm{h}$.

The infusion of glucose was a sufficient stimulus to increase ovulation rate significantly $(2 \cdot 4 \pm 0 \cdot 3$ and $2 \cdot 0 \pm 0 \cdot 0 ; P=0 \cdot 053)$. There were significant effects on plasma concentrations of FSH and prolactin. Before the infusion of glucose, FSH values were not different, but by the end of the period of glucose infusion FSH levels were lower in the treated ewes ( $J_{+} A_{+}$Downing, $J_{+}$Joss \& 
R. J. Scaramuzzi, unpublished results). No differences were observed in prolactin levels for the first $75 \mathrm{~h}$ of the treatment period, but they were higher in the glucose-infused ewes from this time until the end of the infusion (J. A. Downing, J. Joss \& R. J. Scaramuzzi, unpublished results). There were no significant overall treatment effects on plasma growth hormone values although they were higher from 36 to $72 \mathrm{~h}$ after the start of the infusion. With all three hormones there were significant effects of time and significant time $x$ treatment interactions (J. A. Downing, J. Joss \& R. J. Scaramuzzi, unpublished results).

There was no effect of glucose infusion on any of the LH pulse variables (J. A. Downing, J. Joss \& R. J. Scaramuzzi, unpublished results). The mean LH pulse interval was $436 \pm 44$ min for the ewes infused with glucose and $437 \pm 67 \mathrm{~min}$ in the control ewes. Insulin levels were significantly higher in ewes infused with glucose $(P<0.001)$ when compared with corresponding controls (Fig. 4).

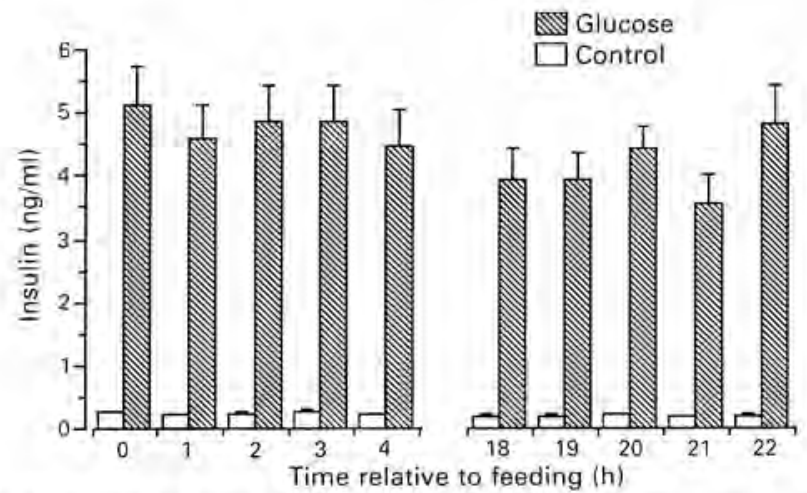

Fig. 4. The levels of insulin in hourly samples of jugular venous plasma from ewes fed a basal diet of wheaten straw containing minerals and infused for 5 days with saline (Control; $N=9$ ) or $25 \%$ dextrose (Glucose; $\mathrm{N}=12$ ). Samples were collected during the mid-luteal phase of the oestrous cycle, from 0 to 4 and from 18 to $22 \mathrm{~h}$ after daily feeding.

Treatment with glucose for 5 days increased ovulation rate without altering $\mathrm{LH}$ and with lower FSH levels. These data do not support the idea that elevated concentrations of gonadotrophins are the means by which dietary energy increases ovulation rate. The changes in the circulating levels of the metabolic hormones are important signals of the metabolic state of the animal and may have been involved in the ovulation responses observed.

\section{Does the supply of precursors for neurotransmitter synthesis regulate ovulation rate?}

The brain of mammals is a very complex structure. It consists of many networks of neural cells that communicate with each other by the synthesis and release of neurotransmitter substances. The ability of neurones to synthesize a specific neurotransmitter depends partly on the availability of precursors that are obtained from the diet. The intake of these precursors may significantly influence the ability of the neuronal cells to synthesize the appropriate transmitter and may consequently affect the functional activity of the cells. Several molecules have been proposed as putative neurotransmitters in the central nervous system (Fig. 5). One characteristic all these share is that they are nitrogenous compounds almost exclusively derived from dietary protein.

The exchange of nutrients between the blood and the brain is regulated by a transport process at the wall of brain blood capillaries and is known as the blood-brain barrier. The blood-brain barrier therefore provides a potential site by which nutrient uptake into the brain can be regulated. 


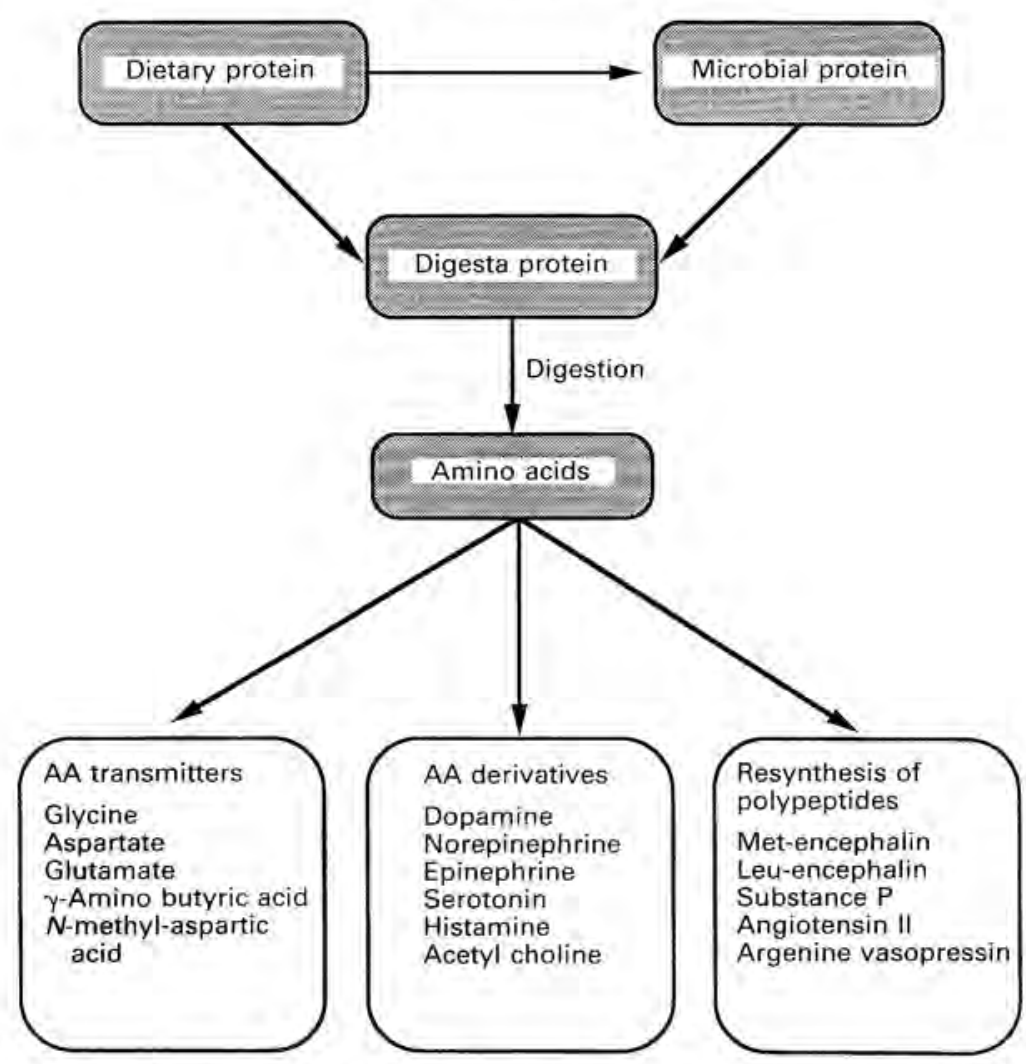

Fig. 5. Biologically active amino acid and amino acid-derived molecules available directly from digestible protein. (Adapted from Lovenberg, 1986.)

There are independent transport systems for various nutrients, one such being for the large neutral amino acids. The rate-limiting step in the movement of these amino acids from the gut to the brain is at the blood-brain barrier. Because the large branched chain amino acids use the same transport system, the uptake of any one of the amino acids is influenced by the levels of all the competing amino acids. The branched-chain amino acids which are likely to be important to the mechanism by which nutrition influences ovulation rate are phenylalanine and tyrosine because they are precursors for the neurotransmitters dopamine, noradrenaline and adrenaline, and tryptophan, the precursor for serotonin. Although very little is known about transport of branched-chain amino acids in sheep, it is possible that improved protein intake by the ewe could alter the uptake of various neurotransmitter precursors and, in turn, alter rates of neurotransmitter turnover which could then influence hypothalamic regulation of gonadotrophin secretion.

In a series of 4 experiments we have infused amino acids (tyrosine; a 1:1 mixture of tyrosine and phenylalanine; aspartic acid; and tryptophan) directly into the peripheral circulation of ewes. The experimental design and bleeding schedule used was the same as used for the infusion of glucose (p. 219), individual amino acids being infused for 5 days (Days 9-13 of the oestrous cycle). There were some differences in the bleeding schedules in 2 of the experiments. With tryptophan infusion, blood samples were taken every $2 \mathrm{~h}$ for $24 \mathrm{~h}$ on the first day of saline infusion followed by a $24 \mathrm{~h}$ period of 20-min samples on the 1st day of tryptophan infusion. No other samples were taken. With tyrosine infusion, the same initial protocol as for tryptophan was followed for the first $48 \mathrm{~h}$. This was followed by an additional period of 4-h sampling which extended from the end of the intensive sampling until $24 \mathrm{~h}$ after the prostaglandin injection given at the end of the infusion. 
The 20-min samples were assayed for $\mathrm{LH}$ and growth hormone and the less frequent samples for prolactin and $\mathrm{FSH}$.

None of the amino acids tested had any significant influence on ovulation rate (Table 1). Tyrosine depressed ovulation rate and this non-significant effect was accompanied by a nonsignificant reduction in $\mathrm{LH}$ pulse frequency. $\mathrm{LH}$ pulse variables were not influenced by the other amino acids. None of the amino acid treatments had effects on prolactin, FSH or growth hormone levels (J. A. Downing, J. Joss \& R. J. Scaramuzzi, unpublished results). These results suggest that increases in the amounts of these amino acids in blood are not likely to be the stimuli for nutritional influences on ovulation rate.

Table 1. The ovulation rate of ewes fed a basal diet of wheaten straw and infused intravenously with various amino acids for 5 days before the induction of luteolysis, induced at the end of the infusion period with a commercially available prostaglandin analogue and ovulation rate was determined, by endoscopy, 10 days later

\begin{tabular}{lcccc}
\hline & & \multicolumn{2}{c}{ Ovulation rate } & \\
\cline { 3 - 4 } & $\begin{array}{c}\text { Rate } \\
\text { (g/ewe/day) }\end{array}$ & $\begin{array}{c}\text { Control } \\
\text { infusion }\end{array}$ & $\begin{array}{c}\text { Amino acid } \\
\text { infusion }\end{array}$ & Significance \\
\hline $\begin{array}{l}\text { Tyrosine } \\
\begin{array}{l}\text { Tyrosine }+ \\
\text { phenylalanine }\end{array}\end{array}$ & 10.9 & $1 \cdot 80 \pm 0.25$ & $1.33 \pm 0.17$ & $P=0.31$ \\
$\begin{array}{l}\text { Tryptophan } \\
\text { Aspartic acid }\end{array}$ & $8 \cdot 3+8.3$ & $2 \cdot 00 \pm 0.00$ & $2 \cdot 09 \pm 0.09$ & $P=0.31$ \\
\hline
\end{tabular}

\section{Effects of infusing a mixture of the branched-chain amino acids on ovulation rate and hormone concentrations in the ewe}

A wide range of metabolic parameters has been measured in wethers fed different levels of protein and energy (Waghorn, 1986). The same diets were fed to ewes, yielding an equation that related the percentage of ewes with multiple ovulation to differences in the energy and protein intake (Smith, 1985). Comparisons between the two sets of data allowed for correlations to be derived between ovulation rate and metabolic variables. The strongest correlation was found between ovulation rate and the plasma concentration of valine plus leucine. When ewes were fed a high protein diet ovulation rate increased, as did the blood levels of the branched-chain amino acids (Waghorn et al., 1990). Close investigation of ovulation responses by individual ewes revealed that ewes in which ovulation number increased from 1 to 2 , the increase in level of blood branched-chain amino acids was twice that found in ewes with no change in ovulation number. Accordingly, leucine, isoleucine and valine could interfere with the uptake of tyrosine, phenylalanine and tryptophan by the brain and so interfere with neurotransmitter synthesis and the hypothalamic control of gonadotrophin secretion.

In an experiment designed to test this hypothesis a mixture of leucine, isoleucine and valine was infused into ewes for 5 days late in the luteal phase of the oestrous cycle. Again the experimental design used was as described for the infusion of glucose (p. 219): 10 ewes were used as controls and 11 were infused with a mixture of leucine, isoleucine and valine at a total rate of $33.1 \mathrm{~g} / \mathrm{ewe} /$ day. This infusion stimulated ovulation rate $(2.4 \pm 0.2$ vs $1.5 \pm 0.2 ; P=0.013)$, with the increase being due to more ewes having 2 or more ovulations. There were no significant treatment effects on the circulating concentrations of FSH (Fig. 6), prolactin or growth hormone (J. A. Downing, J. Joss \& R. J. Scaramuzzi, unpublished results). There were significant time effects but no significant 
time $\times$ treatment interactions for any of these 3 hormones (J. A. Downing, J. Joss \& R. J. Scaramuzzi, unpublished results). The LH pulse characteristics were also unaffected by treatment; the mean pulse frequency over the $24-\mathrm{h}$ sampling period was $5.2 \pm 0.7$ pulses $/ 24 \mathrm{~h}$ and $5.8 \pm 0.6$ pulses $/ 24 \mathrm{~h}$ for the treated and control ewes respectively. The only significant hormonal difference observed was in the circulating concentrations of plasma insulin. Infusion with the mixture of branched-chain amino acids increased insulin levels from $0.3 \pm 0.1 \mathrm{ng} / \mathrm{ml}$ in the control ewes to $1 \cdot 1 \pm 0 \cdot 2 \mathrm{ng} / \mathrm{ml}$.

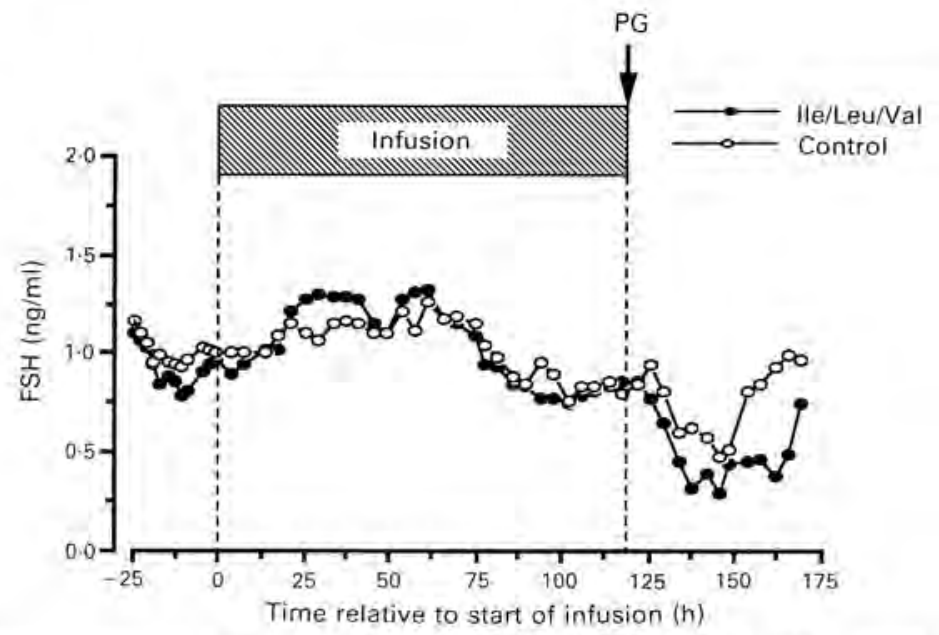

Fig. 6. The concentrations of FSH in 2-h $(-24$ to $0 \mathrm{~h})$ and $4-\mathrm{h}(24$ to $172 \mathrm{~h})$ samples of jugular venous plasma from ewes fed a basal diet of wheaten straw containing minerals and infused for 5 days with either saline (Control; $N=10$ ) or a mixture of the branched-chain amino acids (Ile/Leu/Val; $N=11$ ). The period of infusion is indicated by the hatched bar; luteolysis was induced at the end of the infusion period by the injection of a commercially available prostaglandin preparation (PG).

The ovulation rate response observed was not associated with changes in plasma FSH or LH during the times that these hormones were measured. Again, as with glucose infusion, the data do not support the concept that elevated concentrations of gonadotrophins are the means by which nutrition increases ovulation rate. There was also no observable difference in the levels of prolactin or growth hormone, a result contrary to the effects of lupin grain feeding or with the infusion of glucose. The increase in insulin concentration after infusion with a mixture of the branched-chain amino acids is consistent with our observations with lupin grain feeding and the infusion of glucose and therefore it seems possible that insulin concentrations could be involved in the ovarian response to nutritional stimuli.

\section{Conclusion}

In trying to understand how short-term nutrient supply can increase ovulation rate, we have suggested that changes in the level of atresia during the final stages of follicle development play an important role. Initially, we considered that any change in the level of atresia would be associated with change in the circulating concentrations of gonadotrophins. Thus by increasing FSH and/or LH it would be possible to give additional hormonal support to developing follicles, thereby reducing atresia and increasing the number of activated follicles.

Our first experiments examined the possibility that the increased supply of amino acid precursors for neurotransmitter synthesis would indirectly increase the supply of gonadotrophins to 
the ovary. We were unable to find any effects on ovulation rate or plasma hormone concentrations when tyrosine, tyrosine and phenylalanine, aspartic acid or tryptophan were infused for 5 days in the late luteal phase. Infusion of glucose increased ovulation rate without significant effects on LH pulsing and in the presence of lower circulating concentrations of FSH. As would be expected, major effects were seen in some metabolic hormones. Concentrations of growth hormone and prolactin were elevated but only for a short time during the infusion. The most dramatic increase was in the plasma insulin level. The feeding of lupin grain during the late luteal phase increased ovulation rate but without major effects on circulating gonadotrophin values. The concentrations of the metabolic hormones were significantly altered when lupin grain was fed, prolactin and insulin increased while growth hormone decreased. The infusion of a mixture of leucine, isoleucine and valine for 5 days increased ovulation rate without significant effects on gonadotrophin, prolactin or growth hormone concentrations but with significant increases in insulin values.

From these studies we now consider that if short-term nutritional effects on ovulation rate are mediated by changes in the level of atresia then this does not need to involve increases in circulating gonadotrophin concentrations. We are now persuaded that the metabolic hormones are involved, probably by a direct action on the ovary. The changes in ovulation rate brought about by nutrition occur when the ewe is undergoing metabolic changes. The ewe is losing or gaining weight and so storing or utilizing body reserves. The metabolic state of the animal is reflected in the concentrations of the various metabolic hormones. If the metabolic hormones are involved in the ovulation rate responses, they could provide the link between nutrition and ovulation rate.

Insulin has been shown to increase ovulation rate in the ewe (Hinch \& Roelofs, 1986). Some invitro studies have shown that insulin can augment gonadotrophin stimulated steroidogenesis by cultured granulosa cells (Adashi et al., 1985; Poretsky \& Kalin, 1987). It is possible that insulin could alter levels of follicular atresia by acting to enhance the effects of gonadotrophins in the ovary.

We thank Dr Jean Joss of the school of Biological Science at Macquarie University for her contributions to the unpublished results referred to; and Bronwyn Gordon, Steve Harmer, Colin Maxwell, Joanne Murray, Donna Paliskis, Allan Rintoul, Peter Speck and Keith Turnbull for expert technical assistance.

\section{References}

Adams, N.R. \& Ritar, A.J. (1986) Measurement of estrogen receptors in the ovariectomized ewe is affected by body condition and secondary binding sites. Biol. Reprod. 35, 828-832.

Adashi, E.Y., Resnick, C.E., D'ercole, A.J., Svoboda, M.E. \& Van Wyk, J.J. (1985) Insulin-like growth factors as intraovarian regulators of granulosa cell growth and function. Endocrine Rev. 6, 400-420.

Allen, D.M. \& Lamming, G.E. (1961) Nutrition and reproduction in the ewe. J. agric, Sci., Cambr. 56, 69-79.

Allison, A.J. (1968) The influence of liveweight on ovulation rate in the ewe. Proc. N.Z. Soc. Anim. Prod. 28, $115-119$

Atkinson, S. \& Adams, N.R. (1988) Adrenal glands alter the concentration of oestradiol-17 $\beta$ and its receptor in the uterus of ovariectomized ewes. J. Endocr. 118, $375-380$.

Baird, D.T. \& McNeilly, A.S. (1981) Gonadotrophic control of follicular development and function during the oestrous cycle of the ewe. I. Reprod. Fert., Suppl, 30, 119-133.
Beitz, D.C. (1985) Physiological and metabolic systems important to animal growth: an overview. J. Anim. Sci. 61, 1-20.

Bellows, R.A., Pope, A.L., Meyer, R.K., Chapman, A.B. \& Casida, L.E. (1963) Physiological mechanisms in nutritionally-induced differences in ovarian activity of mature ewes. J. Anim. Sci. 22, 93-100.

Brand, A. \& de Jong, W.H.R. (1973) Qualitative and quantitative micromorphological investigations of the tertiary follicle population during the oestrous cycle in sheep. J. Reprod. Fert. 33, 431-439.

Brien, F.D., Baxter, R.W., Findlay, J.K. \& Cumming, I.A. (1976) Effect of Jupin grain supplementation on ovulation rate and plasma follicle stimulating hormone (FSH) concentration in maiden and mature Merino ewes. Proc. Aust. Soc. Anim. Prod. 11, 237-240.

Cahill, L.P. (1981) Folliculogenesis in the sheep as influenced by breed, season and oestrous cycle. $J$. Reprod. Fert., Suppl. 30, 135-142.

Cahill, L.P. \& Mauleon, P. (1980) Influences of season, cycle and breed on the follicular growth rates in sheep. J. Reprod. Fert. 58, 321-328. 
Cahill, L.P., Mariana, J.C. \& Mauléon, P. (1979) Total follicular populations in ewes of high and low ovulation rates. J. Reprod. Fert. 55, 27-36.

Carson, R.S., Findlay, J.K., Burger, H.G. \& Trounson, A.O. (1979) Gonadotrophin receptors of the ovine ovarian follicle during follicular growth and atresia. Biol. Reprod. 21, 75-87.

Clark, R.T. (1934) Studies on the physiology of reproduction in the sheep 1 . The ovulation rate of the ewe as affected by the plane of nutrition. Anat. Rec. 60 , 125-134.

Coop, I.E. (1962) Liveweight-productivity relationships in sheep. N,Z. Jl agric. Res. 5, 249-264.

Coop, I.E. (I966) Effect of flushing on reproductive performance of ewes. J. agric. Sci., Cambr, 67, 305-323.

Corbett, J.L. \& Edey, T.N. (1977) Ovulation in ewes given formaldehyde-treated casein in maintenanceenergy rations. Aust. J. agric. Res. 28, 491-500.

Cruickshank, G.J., Smith, J.F. \& Fraser, D.G. (1988) The influence of abomasal infusion of protein or energy on ovulation rate in ewes. Proc. N.Z. Soc. Anim. Prod 48, 77-79.

Cumming, I.A. (1977) Relationship in the sheep of ovulation rate with liveweight, breed, season, and plane of nutrition. Aust. J. exp. Agric. Anim. Hus. 17, 234-241.

Darrock, J.G., Nordskog, A.W. \& Van Horn, J.L. (1950) The effect of feeding concentrates tó range ewes on lamb and wool productivity. J. Anim. Sci. 9, 431-445.

Davis, I.F., Brien, F.D., Findlay, J.K. \& Cumming, I.A. (1981) Interactions between dietary protein, ovulation rate and follicle stimulating hormone in the ewe. Anim. Reprod. Sei. 4, 19-28.

Ducker, M.J. \& Boyd, J.S. (1977) The effect of body size and body condition on the ovulation rate of ewes. Anim. Prod. 24, 377-385.

Dufour, J.J. \& Matton, P. (1977) Identification of ovarian follicles at estrus and development of their ensuing corpora lutea in single and multiple ovulating ewes on two feeding regimes. Can. J. Anim. Sci. 57, 647-652.

Edey, T.N. (1968) Body weight and ovulation rate in sheep. Proc, Aust. Soc. Anim. Prod. 7, 188-19I.

England, B.G., Webb, R. \& Dahmer, M.K. (1981) Follicular steroidogenesis and gonadotrophin binding to ovine follicles during the estrous cycle. Endocrinology $109,881-887$.

Findlay, J.K. \& Cumming, I.A. (1976) FSH in the ewe: Effects of season, live weight and plane of nutrition on plasma FSH and ovulation rate. Biol. Reprod. 15, 335-342.

Fletcher, 1.C. (1981) Effects of energy and protein intake on ovulation rate associated with the feeding of lupin grain to Merino ewes. Aust, I, agric, Res. 32, 79-87.

Gherardi, P.B. \& Lindsay, D.R. (1980) The effect of season on the ovulatory response of Merino ewes to serum from pregnant mares. $J$. Reprod. Fert. 60, 425-429.

Greep, R.O. (1961) Physiology of the anterior hypophysis in relation to reproduction. In Sex and Internal Secretions, pp. 240-301. Ed. W. C. Young. Williams \& Wilkins, Baltimore.

Gunn, R.G. \& Doney, J.M. (1975) The interaction of nutrition and body condition at mating on ovulation rate and early embryo mortality in Scottish Blackface ewes, J. agric, Sci., Cambr, 85, 465-470.

Gunn, R.G., Doney, J.M. \& Russel, A.J.F. (1969) Fertility in Scottish Blackface ewes as influenced by nutrition and body condition at mating. J. agric. Sci., Cambr. 73, $289-294$.

Gunn, R.G., Doney, J.M. \& Russel, A.J. (1972) Embryo mortality in Scottish Blackface ewes as influenced by body condition at mating and post-mating nutrition. J. agric. Sci., Cambr. 79, 19-25.

Gunn, R.G., Doney, J.M. \& Smith, W.F. (1984a) The effect of different durations and times of high-level feeding prior to mating on the reproductive performance of Scottish Blackface ewes. Anim. Prod. 39, 99-105.

Gunn, R.G., Doney, J.M. \& Smith, W.F. (1984b) The effect of level of pre-mating nutrition on ovulation rate in Scottish Blackface ewes in diflerent body conditions at mating. Anim. Prod. 39, 235-239.

Hammond, J., Jr (1952) Nutrition and fertility. Proc, 6th Int. Congr. Animal Husbandry, Hamburg, pp. 38-45.

Haresign, W. (1981) The influence of nutrition on reproduction in the ewe. 1. Effects on ovulation rate, follicle development and luteinizing hormone release. Anim. Prod. 32, 197-202.

Hart, G.H. \& Miller, R.F. (1937) Relation of certain dietary essentials to fertility in sheep. J. agric. Res. $55,47-58$.

Heape, W. (1899) Abortion, barrenness and fertility in sheep. J. Roy. agric. Soc. (3rd ser.) 10, 217-248.

Hemsell, D.L., Grodin, J.M., Brenner, P.F., Siiteri, P.K. \& MacDonald, P.C. (1974) Plasma precursors of estrogen. II. Correlation of the extent of conversion of plasma androstenedione to estrone with age. $J$. clin. Endocr. Metab. 38, 476-479.

Hinch, G.N. \& Roelofs, J.H.W. (1986) Lupin feeding and insulin infusion during the late luteal phase can increase ovulation rate in sheep. Proc. Aust. Soc. Reprod. Biol. 18, 43, abstr.

Howland, B.E., Kirkpatrick, R.L., Pope, A.L. \& Casida, L.E. (1966) Pituitary and ovarian function in ewes fed on two nutritional levels. J. Anim. Sci. 25 , 716-721.

Hsueh, A.J.W., Adashi, E.Y., Jones, P.B.C. \& Welsh, T.H. (1984) Hormonal regulation of the differentiation of cultured ovarian granulosa cells. Endocr. Rev. 5, 76-127.

Kelly, R.W. \& Johnstone, P.D. (1982) Reproductive performance of commercial sheep flocks in South Island districts. 2-Relationships between ovulation rate, liveweight, mating and lambing performance. N.Z. $J$. agric. Res. 25, 519-523.

Kelly, R.W., Thompson, K.E., Hawker, H., Crosbie, S.F. \& McEwan, J.C. (1983) Liveweight, ovulation rate and wool growth responses of light and heavy ewes to differential feeding. N.Z. Jlexp. Agric. 11, 219-224.

Killeen, I.D. (1967) The effects of bodyweight and level of nutrition before, during and after joining on ewe fertility. Aust. J. exp. Agric. Anim. Husb. 7, 126-136.

Kleeman, D.O. \& Cutten, I.N. (1978) The effects of frequency of feeding a lupin grain supplement at mating on the reproductive performance of maiden and mature Merino ewes. Aust. J. exp. Agric. Anim. Husb. 18, $643-647$. 
Knight, T.W. (1980) Effects of diet and liveweight on ovulation rates in Romney ewes. Proc. N,Z. Soc. Anim. Prod. 40, 38-42.

Knight, T.W., Oldham, C.M. \& Lindsay, D.R. (1975) Studies in ovine infertility in agricultural regions in Western Australia: the influence of a supplement of lupins (Lupinus augustifolius cv. Uniwhite) at joining on the reproductive performance of ewes. Aust. $J$. agric. Res. 26, 567-575.

Knight, T.W., Payne, E. \& Peterson, A.J. (1981) Effect of diet and liyeweight on FSH and oestradiol concentrations in Romney ewes. Proc. Aust. Soc. Reprod. Biol. 13, 19, abstr.

Lightfoot, R.J. \& Marshall, T. (1974) The effects of pasture type and lupin grain supplementation on ovulation rate of Merino ewes. 1-Rate of lupin grain supplementation. J. Agric., W.A. (4th ser.) 15, $29-31$.

Lindsay, D.R. (1976) The usefulness to the animal producer of research findings in nutrition on reproduction. Proc. Aust. Soc. Anim. Prod. 9, 217-224.

Lovenberg, W.M. (1986) Biochemical regulation of brain function. Nutrition Reviews, May, pp, 6-11.

Marshall, F.H.A. (1904) Fertility in sheep. Trans. Highland agric. Soc: 16, 34-43.

Marshall, F.H.A. (I905) Fertility in Scottish sheep. Proc. R. Soc. Lond. B77, 58-62.

Marshall, F.H.A. (1908) Fertility in Scottish sheep. Trans. Highland agric, Soc. 20, 139-151,

Marshall, F.R. \& Potts, C.G. (1921) Flushing and other means of increasing lamb yields. United States Department of Agriculture, Bulletin No 966, 1-14.

MeNatty, K.P. (1982) Ovarian follicular development from the onset of luteal regression in humans and sheep. In Follicular Maturation and Ovilation, pp. I-18. Eds R. Rolland, E. V, Van Hall, S, G. Hillier, K. P. McNatty \& J. Schoemaker. Excerpta Medica Press, Amsterdam.

MeNatty, K.P., Hudson, N., Gibb, M., Ball, K., Henderson, K.M., Heath, D.A., Lun, S. \& Kieboom, L.E. (1985) FSH influences follicle viability, oestradiol biosynthesis and ovulation rate in Romney ewes. $J$. Reprod. Fert. 75, 121-131.

Memon, G.N., Antoniewicz, R.J., Benevenga, N.J., Pope, A.L. \& Casida, L.E. (1969) Some effects of differences in dietary energy and protein levels on the ovary and the anterior pituitary gland of the ewe. J. Anim. Sci. 28, 57-62.

Memon, G.N., Patel, B.M. \& Buch, N.C. (1971) Effect of dietary energy from hydrogenated vegetable oil and starch on ovarian and anterior pituitary gland response in ewes. Ind. J. Anim. Sci. 41, 685-689.

Moore, P.J. \& Greenwaid, G.S. (1974) Effects of hypophysectomy and gonadotrophin treatment on follicular development and ovulation in the hamster. $A m . J$. Anat. 139, 37-48.

Morley, F.H.W., White, D.H., Kenney, P.A. \& Davis, I.F. (1978) Predicting ovulation rate from liveweight in ewes. Agric. Systems 3, 27-45.

Nichols, J.E. (1924) Fertility in sheep. I. Min. Agric. 31, 835-843.

Nichols, J.E. (1926) Fertility in Southdown sheep, $J$. agric. Sci., Cambr, 16, 365-375.

Nottle, M.B., Setchell, B.P. \& Seamark, R.F. (1986) Supplementation with lupin grain for six days can increase induced ovulation rate in the ewe. Proc. Nutrit.Soc. Austr. 11, 239, abstr.

Nottle, M.B., Setchell, B.P. \& Seamark, R.F. (1987) Short-term supplementation with lupin grain increases serum FSH in the ovariectomised, oestradiolimplanted ewe. Proc. Austr. Soc. Reprod. Biol. 19, 37. abstr.

Nottle, M.B., Hynd, P.I., Seamark, R.F. \& Setchell, B.P. (1988) Increases in ovulation rate in lupin-fed ewes are initiated by increases in protein digested postruminally, $I$. Reprod. Fert. 84, 563566.

Oldham, C.M. \& Lindsay, D.R. (1984) The minimum period of intake of lupin grain required by ewes to increase their ovulation rate when grazing dry summer pasture. In Reproduction in Sheep, pp. 274 275. Eds D. R. Lindsay \& D. T. Pearce. Australian Academy of Sciences. Canberra.

Poretsky, L. \& Kalin, M.F. (1987) The gonadotropic function of insulin. Endocrine Rev. 8, 132-141.

Radford, H.M., Donegan, S. \& Scaramuzzi, R.J. (1980) The effect of supplementation with lupin grain on ovulation rate and plasma gonadotrophin levels in adult Merino ewes, Anim. Prod. Austr. 13, 457, abstr.

Rhind, S.M. \& MeNeilly, A.S. (1986) Follicle populations, ovulation rates and plasma profiles of LH. FSH and prolactin in Scottish Blackface ewes in high and low body condition. Anim. Reprod. Sci. 10, $105-115$

Rhind, S.M., Leslie, L.D., Gunn, R.G. \& Doney, J.M. (1985) Plasma FSH, LH, prolactin and progesterone profiles of Cheviot ewes with different levels of intake before and after mating, and associated effects on reproductive performance. Anim. Reprod. Sci. 8 , $301-313$.

Rhind, S.M., Martin, G.B., MeMillen, S., Tsonis, C.G. \& McNeilly, A.S. (1989a) Effect of level of food intake of ewes on the secretion of luteinizing hormone ( $\mathrm{LH}$ ) and follicle stimulating hormone (FSH) and on the pituitary response to gonadotrophin-releasing hormone $(\mathrm{GnRH})$ in ovariectomized ewes. $I_{+}$Endocr. 121, 325-330.

Rhind, S.M., McMillen, S., Wetherill, G.Z., McKelvey, W.A.C. \& Gunn, R.G. (1989b) Effects of low levels of food intake before and/or after mating on gonadotrophin and progesterone profiles in Greyface ewes. Anim. Prod. 49, 267-273.

Richards, J.S. (1980) Maturation of ovarian follicles: actions and interactions of pituitary and ovarian hormones on follicular cell differentiation. Physiol. Rey. $60,51-89$.

Ritar, A.J. \& Adams, N.R. (1988) Increased ovulation rate, but not FSH or $\mathrm{LH}$ concentrations, in ewes supplemented with lupin grain. Anim. Prod. Austr. $17,310-313$.

Rizzoli, D.J., Baxter, R., Reeve, J.L. \& Cumming, I.A. (1976) Effect of lupin grain supplementation on ovulation rate in Border Leicester $\times$ Merino ewes. $J$, Reprod. Fert. 46, 518-519.

Russel, A.J.F., Doney, J.M. \& Gunn, R.G. (1969) Subjective assessment of body fat in live sheep. J. agric. Sit., Cambr. 72, 451-454.

Scaramuzzi, R.J. (1986) Fertility, prolificacy and their relationship to nutrition. In Proc, 6/h Int Conf. Production, Disease in Farm Animals, pp. 301-311. Eds 
C. H. Murray, D. A. Murray, S. Kennedy \& M. McLoughlin,

Scaramuzzi, R.J. \& Radford, H.M. (1983) Factors regulating ovulation rate in the ewe. J. Reprod. Fert. 69, 353-367.

Smeaton, D.C., Knight, T.W. \& Winn, G.W. (1981) Problems in flushing ewes on North Island hill country Proc. N.Z. Soc, Anim. Prod. 41, 183-188.

Smith, J.F. (1985) Protein, energy and ovulation rate. In Genetics of Reproduction in Sheep, pp. 349-359. Eds R. B. Land \& D. W. Robinson. Butterworth Scientific, London.

Smith, J.F. (1988) Influence of nutrition on ovulation rate in the ewe. Aust, J. biol Sci. 41, 27-36.

Stewart, R. \& Oldham, C.M. (1986) Feeding lupins to ewes for four days during the luteal phase can increase ovulation rate. Anim. Prod. Aust. 16, 367-369.

Teleni, E., Rowe, J.B., Croker, K.P., Murray, P.J. \& King, W.R. (1989) Lupins and energy-yielding nutrients in ewes II Responses in ovulation rate in ewes to increased availability of glucose, acetate and amino acids. Reprod. Fert., Devel. 1, 117-125.

Thompson, W. \& Aitken, F.C. (1959) Diet in relation to fertility, reproduction and lactation: Effect of plane of nutrition of ewe on fertility, reproduction and lactation. Commonwealth Bureau of Animal Nutrition, Technical Communication No. 20, 67-93.

Tonetta, S.A. \& diZerega, G.S. (1989) Intragonadal regulation of follicular maturation. Endoct Rev. 10, 205-229.

Torell, D.T., Hume, I.D. \& Weir, W.C. (1972) Effect of level of protein and energy during flushing on lambing performance of range ewes. J. Anim. Sci. 34, 479-482.

Tribe, D.E. \& Seebeck, R.M. (1962) Effect of live-weight and liveweight change on the lambing performance of ewes. J. agric. Sct., Cambr. 59, 105-110.

Turnbull, K.E., Braden, A.W.H. \& Mattner, P.E. (1977) The pattern of follicular growth and atresia in the ovine ovary. Aust. J. biol. Sci. 30, 229-241.

Underwood, E.J. \& Shier, F.L. (1941) Studies in sheep husbandry in Western Australia. I. The effect of nutritional "flushing" upon fertility. J. Agric. West. Austr. 18, 13-21.

Waghorn, G.C. (1986) The effect of different protein/ energy intakes on nutritional and physiological parameters in young sheep. Proc. N.Z. Soc. Anim Prod. 46, 31-35.

Waghorn, G.C., Smith, J.F. \& Ulyatt, M.J. (1990) Effect of protein energy intake on digestion and nitrogen metabolism in wethers and on ovulation in ewes. Anim. Prod. (in press).

Wallace, L.R. (1951) Flushing of ewes. N.Z. J. Agric. 82, 377-380.

Wallace, L.R. (1953) Management of the fat lamb flock. N.Z. J. Agric, 87, 529-535.

Wallace, L.R. (1954) Studies in the augmentation of fertility of Romney ewes with pregnant-mare serum. J. agric. Sci., Cambr, 45, 60-79.

Wallace, L.R. (1958) Breeding Romneys for better lambing percentages. Proc. Ruakura Farmers Conference Week, 62-73.

Wallace, L.R. (1961) Influence of liveweight and condition on ewe fertility. Proc, Ruakura Farmers Conference Week, 14-25,

Webh, R. \& Gauld, I.K. (1985) Folliculogenesis in sheep: control of ovulation rate. In Genetics of Reproduction in Sheep, pp. 261-274. Eds R. B. Land \& D. W. Robinson. Butterworth Scientific, London.

Webb, R., Gauld, I.K. \& Land, R.B. (1984) Seasonal independence of follicle development in the ewe. Proc. 10th Int. Congr. Anim. Reprod \& A.I., UrbanaChampaign 10, 498-499.

Xu, Z.Z., McDonald, M.F. \& McCutcheon, S.N. (1989) The effects of nutritionally-induced liveweight differences on follicular development, ovulation rate. oestrous activity and plasma follicle-stimulating hormone levels in the ewc. Anim. Reprod. Sci. 19, $67-78$.

Youatt, W. (1837) Sheep: Their Breeds, Management and Diseases. Baldwin and Craddock, London. 